\title{
粗
}

\section{Oor die Bybel, Bybellees en etiek: in gesprek met Gerrie Snyman ${ }^{1}$}

\author{
J.H. van Wyk
}

Navorser: Skool vir Kerkwetenskappe

Potchefstroomkampus

Noordwes-Universiteit

POTCHEFSTROOM

E-pos: amievw@intekom.co.za

\section{Abstract \\ On the Bible, Bible reading and ethics: in debate with Gerrie Snyman}

Without doubt Gerrie Snyman produced a book which attests to an existential grappling with questions about Christian faith, the Bible and understanding of the Bible. The author refers to apartheid, women in office and homosexual persons as examples of misunderstanding and misuse of the Bible. He advocates a reinterpretation of the Bible in which the authors (of the Bible), the context of the authors, the context of the first and the context of the modern readers be taken into account fully. The classic way of reading the Bible is outdated and should be exchanged for a more critical approach to the Bible. The author of this article investigates the question as to whether Snyman is not guilty of a naïve form of rationalism and relationism.

\section{Opsomming}

Oor die Bybel Bybellees en etiek: in gesprek met Gerrie Snyman

Dit lei geen twyfel nie dat Gerrie Snyman met sy jongste boek navorsing gelewer het wat van eksistensiële worsteling getuig

$1 \quad$ Na aanleiding van die boek van Gerrie Snyman (2007). Dit val op dat daar die afgelope dekades, vanuit verskillende gesigspunte, uitgebreid oor die Skrifvraagstuk in Suid-Afrika besin is (vgl. onder andere Heyns (1973); Van Huyssteen \& Du Toit (1982); Deist (1986; 1994); Mosala (1989); Van Wyk (1989); Potgieter (1990); West (1991); Spangenberg (1998); König (2002); Nürnberger (2002); Van der Watt et al. (2002); Smit (2006); Malan (2008a)). Vergelyk ook Van Niekerk (2005:35-53). 
met vrae wat oor die Christelike geloof, die Bybel en Bybelverstaan handel. As voorbeeld van 'n misverstaan van die Bybel verwys hy herhaaldelik na apartheid, die vrou in die amp en homoseksuele persone. Hy bepleit 'n totale herverstaan van die Bybel waarin deeglik rekening gehou word met onder andere die Bybelskrywer, die konteks van die skrywer, die konteks van die eerste lesers en die konteks van die moderne leser. Die klassieke manier van Bybellees is uitgedien en moet laat vaar word ten gunste van 'n meer kritiese omgang met die Bybel. Die skrywer van hierdie artikel ondersoek die vraag of Snyman hom nie hiermee dalk skuldig maak aan 'n naïewe vorm van rasionalisme en relasionisme nie. 2

\section{Inleiding}

Op die agterblad van Snyman se boek verskyn 'n foto van die skrywer met 'n ondeunde glimlag, asof hy wil sê: hier kom 'n ding! En inderdaad: hier kom 'n ding!

Snyman is oortuig daarvan dat die wyse waarop die Bybel gebruik is om apartheid te ondersteun, en tans aangewend word teen vroue in die kerklike ampte asook teen homoseksuele persone, 'n beskawingsbreuk (en ook vertrouensbreuk) in kerk en teologie veroorsaak het. Ons kan eenvoudig nie meer die Bybel op die ou (naïewe) manier lees nie. 'n Ander manier van Bybellees het noodsaaklik geword; 'n kontekstuele manier waar rekening gehou word met die konteks van die Bybelskrywer, die teks en die konteks van die eerste en latere lesers. Dit is duidelik dat die skrywer met kritiese oë kyk na die Skrifverstaan en Skrifgebruik in die reformatoriese tradisie en belydenis waarin hy opgegroei het en dat hy in 'n bepaalde sin daarvan afskeid neem.

In dertien hoofstukke word die hooftema breedvoerig, en telkens herhalend, aan die orde gestel. Die inleidende hoofstuk handel oor "want die ander sien ons nie raak nie"; hoofstuk 1 gee aandag aan "Hoekom 'n ander soort lees regtig nodig is"; hoofstuk 2: "Homoseksualiteit en 'n heteroseksuele ideologie"; hoofstuk 3: "'n Etiek van (Bybel)lees"; hoofstuk 4: "Geweld en die Bybel as wapen"; hoofstuk

2 Onder rasionalisme verstaan ek daardie filosofiese sisteem waarvolgens aan die menslike verstand die hoogste waarde toegeken word om fundamentele waarhede te ontdek. Onder naïewe rasionalisme word verstaan dat hierdie kenteorie op onkritiese, onderdeurdagte (en meestal onbewuste) wyse hanteer word en dat daaraan in elk geval 'n meerwaarde toegeken word, bo die standpunt dat God Hom aan die mens openbaar. 
5: "Die mite van 'n letterlike lees"; hoofstuk 6: "Kanon en die inspirasie: die status van die teks"; hoofstuk 7: "Die Bybel en mag"; hoofstuk 8: "Lees met 'n 'ander' in gedagte"; hoofstuk 9: "Die Bybelteks as ander"; hoofstuk 10: "Om goed met goeie redes te kan lees; hoofstuk 11: "Om die Bybel anders te sien"; die slothoofstuk het as tema: "Bybellees en die Bybel self as 'n sosiale en kulturele verskynsel".

\section{Die hoofargument}

Hier word voorlopig volstaan deur aandag aan die hoofargument te gee. Ander argumente sal later in die diskussie ter sprake kom.

In die boek word herhaaldelik daarop gewys dat die Bybelteks nie direk toeganklik en duidelik en outomaties 'n welwillende teks is nie (p. 127, 1533). Bybellees is 'n komplekse saak wat meestal ideologies beïnvloed word.

Twee aanhalings illustreer hierdie benadering:

Dit [Sensitiewe Bybellees] is 'n komplekse proses wat ten beste in terme van verskillende verhoudings beskryf kan word: tussen die skrywer en die teks, die skrywer en die wêreld van waaruit geskryf word, tussen die leser en die teks, die leser en die wêreld waarbinne gelees word, die leser en die skrywer, die teks en ander tekste, die teks en die historiese wêreld waarna die teks verwys, die leser en die verhaalwêreld, die leser en die historiese wêreld, die skrywer en die verhaalwêreld, die skrywer en die historiese wêreld. Kortom, die skrywer, die teks, die leser en die Ander. (p. 149-151.)

Op p. 187 word dit weer só geformuleer:

Die klem het verskuif van die vraag na die betekenis van 'n teks na daardie faktore wat ons lees en uiteindelike verstaan van die Bybel beïnvloed, naamlik die wêreld van die teksproduksie, die historiese wêreld waarna die teks verwys, die storiewêreld, die wêreld van die eerste lesers en die wêreld van die huidige leser.

Gevolglik verset die skrywer hom teen elke vorm van simplistiese, naïewe, fundamentalistiese en onsensitiewe vorm van Bybellees, wat die klassieke (ook gereformeerde) teologie kenmerk. Hy ver-

3 Verwysings wat slegs met 'n bladsynommer aangedui word, verwys na Snyman (2007). 
werp (wat hy noem) 'n emiese lees van die Bybel en kies vir 'n etiese lees as gevolg waarvan dit moontlik word om deur middel van buite-Bybelse inligting aan te toon dat waardes wat in die Bybel voorkom, nie Godsopenbaring is nie maar "gewoon gemeenskapswaardes [is] wat in die Bybelverhale goddelike gesag verkry" (p. 182). Die kritiese Bybelwetenskap lewer syns insiens vrugbaarder en sinvoller resultate as die klassieke (reformatoriese) benadering. Duidelike voorbeelde hiervan is te vind in die wyse waarop die Bybel misbruik is (en word) ten opsigte van apartheid, die vrou in die amp en homoseksuele persone.

Hiermee is uiteraard nog glad nie na alle aspekte in die boek verwys nie, maar na, soos ek die boek verstaan, die hoofargument wat daarin te vind is.

\section{Belangrike perspektiewe}

Minstens vier aspekte kan in hierdie verband vermeld word.

Eerstens meen ek dat die skrywer hom ten regte verset teen 'n slordige en simplistiese Skrifgebruik, waar byvoorbeeld 'n standpunt apriories vir of teen 'n saak ingeneem word en dan na 'n aantal Bybeltekste gesoek word om daardie standpunt te onderlê. Die kerkgeskiedenis, ook dié van die Gereformeerde Kerke in Suid-Afrika, is vol van sulke (beskamende) voorbeelde. 4

Tweedens is dit belangrik dat, by die interpretasie van 'n teks, aandag behoort gegee te word aan die verskillende ter sake kontekste (vgl. Joubert aangehaal in Van der Watt et al., 2002:112-113). Ek wil

4 As ekstreme voorbeeld verwys ek hier na die volgende besluit van die GKSA in 1942, ses jaar voordat apartheid in 1948 sy politieke beslag gekry het:

Die sinodale vergadering van die Geref. Kerk in Suid-Afrika wil ten sterkste protesteer teen die voorgenome bewapening van nie-blankes [naturelle en kleurlinge]. Die bewapening is volksgevaarlik, in stryd met ons Christelike volkstradisies en druis in teen ons sendingbeleid.

(GKSA, 1942:30.)

In hierdie besluit is die ideologiese vooroordeel duidelik sigbaar, terwyl 'n deugdelike teologiese fundering ontbreek. Vir 'n bespreking van sinodebesluite van die GKSA oor veral etiese sake, vergelyk Van der Walt (1989). Vergelyk in hierdie verband die welmenende geskrif van Van der Dussen (2006), wat duidelik getuig van 'n ortodoksistiese benadering. Vergelyk byvoorbeeld die volgende (ongereformeerde) uitspraak: "'n Gereformeerde Kerk is 'n Kerk wat klaar gereformeer het." (Van der Dussen, 2006:3 en 24-26). Hierdie skrywer toon weinig begrip vir wat die Nuwe Testament oor die eenheid van die kerk leer en vir die Nuwe-Testamentiese ekklesiologie in die algemeen. 
graag toegee dat die hoofargument van Snyman 'n belangrike waarheid bevat. Dit is inderdaad noodsaaklik dat die verskillende kontekste van 'n teks deeglik verreken behoort te word ten einde die boodskap daarvan reg te verstaan. (Hierdie argument kan natuurlik ook te ver deurgevoer word, sodat niemand uiteindelik kan verstaan wat iemand lank gelede geskryf en bedoel het nie.)

Dit is ' $n$ ou (selfs voor-) reformatoriese beginsel dat ' $n$ bepaalde Bybelteks altyd binne sy bepaalde "teologiese" konteks, asook die kultuurhistoriese konteks van destyds en van vandag gelees behoort te word. $\mathbf{5}$ Dat hierdie beginsel dikwels nie behoorlik in die gereformeerde tradisie gefunksioneer het nie, moet ongetwyfeld as ' $n$ groot nalatigheid en leemte aangemerk word. 'n Goeie voorbeeld van hoe bevrydend die toepassing van hierdie beginsel kan werk, kan gesien word in die bevinding dat slawerny onbybels is en dat die dra van 'n hoed of hoofbedekking na 'n erediens deur vroue 'n opsionele saak is.

Derdens is die opmerking waardevol dat geen Bybelleser die Bybel onbevooroordeeld lees nie maar altyd vanuit bepaalde vooronderstellings ( $p .58$ ). Ideologiese vooronderstellings by die leser kan inderdaad ' $n$ deurslaggewende rol speel by die verstaan van ' $n$ bepaalde teks in die besonder en die Bybel in die algemeen (vgl. ook Smit, 2006:70, 75, 133). (Hierdie opmerking geld natuurlik vir die outeur self en laat die vraag ontstaan of sy eie vooronderstellings altyd duidelik en altyd deeglik in sy argumentasie verreken is.)

Vierdens vestig die outeur tereg ons aandag op die tragiese en onmenslike gevolge wat 'n oppervlakkige en slordige lees van die Bybel kan veroorsaak. Ons verstaan van die Bybel raak mense direk en persoonlik - mense geskape na die beeld van God. So het die teologiese regverdiging van apartheid byvoorbeeld 'n diepgaande, ontwrigtende en verpletterende invloed op individue, gesinne, gemeentes en gemeenskappe uitgeoefen.

$5 \quad$ Velema (1997:118-119) praat in hierdie verband van dekontekstualisering en rekontekstualisering. 


\section{Kritiese diskussie}

\subsection{Wat is die waarde van die Bybel? Oor Skrifbeskouing}

Dit is duidelik dat Snyman ongemaklik is met die klassieke reformatoriese Skrifbeskouing van "die Bybel is Godsopenbaring", omdat dit elke vorm van kontekstualiteit ondermyn, aanleiding gee tot 'n naïewe Skrifinterpretasie as gevolg waarvan die boodskap van die Bybel misverstaan en selfs misbruik word - en dit alles dikwels ten koste van medemense. Hierteenoor kies die skrywer vir die SuidAfrikaanse Grondwet as "hermeneutiese raamwerk" (p. 2). Die vraag ontstaan egter: op grond waarvan word hierdie keuse gemaak? Waar kom die beginsels van die Grondwet vandaan?

Snyman oordeel: "die teenwoordigheid van waardes en norme in die Bybelverhale, en daargestel deur die Bybelskrywers, beteken nie dat die lesers moet aanvaar dat die Bybel 'n onskuldige boek is en dat die leser altyd goedertrou moet wees nie" (p. 72). "Die lewensetiek van die antieke wêreld kan nie bindend wees vir die Bybelleser van die 21ste eeu nie." (p. 74.)

Die skrywer het oortuigend aangetoon dat by die verstaan van elke teks die enger en wyer, ouer en jonger kontekste deeglik verreken behoort te word. Omdat die gedagte van Godsopenbaring by hom egter 'n beperkte en verskraalde rol speel, ontstaan die vraag hoe belangrik die Bybelboodskap inderdaad nog is. Word aan die kontekste nie so 'n deurslaggewende rol toegeken dat die teks uiteindelik oorbodig word nie? Anders gesê: as ons 'n goeie Grondwet het, waarom is die Bybel (bv. as etiese riglyn) dan nog nodig?

Die volgende vrae dring hulle onafwendbaar op: As die Bybelskrywers bloot die morele waardes van hulle tyd weerspieël, watter waarde het die Bybel dan eintlik? Waarom dan soveel aandag aan juis die Bybel bestee? Is die Bybel hoegenaamd nodig? ${ }^{6}$ Besit die Bybel enigsins meer gesag (en waarde) as enige ander boek?

$6 \quad$ Vergelyk in hierdie verband die (teologies ontoereikende) verklaring van Spangenberg (1998:115-118) oor "waarom het ons die Bybel nodig?" Vergelyk ook die kritiek van Van Niekerk op Spangenberg (wat Van Niekerk van fundamentalisme beskuldig het):

Die basiese probleem met Spangenberg se wetenskapsbegrip is dat hy kennelik van oordeel is dat 'n suiwer tekshistoriese ondersoek genoeg 'feitelike kennis' kan oplewer om 'n ganse teologie te 'begrond' - ook al kom die somtotaal van daardie 'teologie' in wese neer op weinig minder as 'n 'weerlegging' van die ganse tradisie van Christelike teologie. (Van Niekerk, 2007:681.) 
Waarin is die gesag van die Bybel geleë? Is die Bybel slegs waardevol omdat dit "ons beïnvloed, ons aanraak en ons laat dink"? (p. 180.) Maar alle (goeie) boeke doen dit tog? Hoe kan die volgende stelling begrond word: "Wanneer 'n mens die Bybel vanuit 'n ander stel waardes lees, word die Bybel nie noodwendig oorbodig nie"? (p. 106.)

In kort, nêrens in die boek blyk die "meerwaarde" van die Bybel ten opsigte van ander geskrifte nie en word die vraag onbeantwoord gelaat waarom juis aan die Bybel soveel aandag bestee behoort te word.

Is daar vir die skrywer hoegenaamd sprake van 'n Goddelike faktor ten opsigte van die Bybel - en indien wel, waar(in) is dit te sien? Dit blyk nie baie duidelik - as ek goed gelees het - dat die Bybel 'n normatiewe teks is waaraan prioriteit bo ander geskrifte verleen behoort te word nie. Dan dring die vraag homself herhaaldelik na vore: Waarom soveel aandag aan juis die Bybel bestee? Daar word wel gesê dat "wanneer ons die Bybel vanuit 'n ander stel waardes lees, die Bybel nie noodwendig oorbodig word nie" (p. 106), maar die begronding vir hierdie groot aanname ontbreek. Is die Bybel slegs "gewone literatuur" (p. 107)?

Lees ons - in die benadering van Snyman - die Bybel anders, of lees ons dalk 'n ander Bybel?

\subsection{Vrae oor die Godsleer}

Dit is duidelik dat die skrywer groot probleme ervaar met die OuTestamentiese Godsbeeld (p. 31-33). "Vir die ou antieke Israeliete was Jahwe 'n stormgod wat reën gegee het" (p. 70). ${ }^{7}$ In die Ou Testament "is daar verskillende sienings oor God en baie keer is die sienings teenstrydig met mekaar" (p. 166). Lesers moet vandag uit hierdie repertorium van Godsbeelde een kies om ons eie lewe en die lewe van ander mense draagliker te maak (p. 180). Die Ou Testament bring ons te staan voor die vraag na 'n "gewelddadige God", soos byvoorbeeld in die intoggeskiedenis van Israel en in die boek Ester gesien kan word (p. 158-159, 190).8

7 Dieselfde gedagte is ook by De Klerk (1998:53) te vind: "Israel het hulle God ook aanvanklik as 'n stamgod gesien - Hy was een van vele gode ... Eers later word alle gode as niegode verklaar ..."

8 Vergelyk hier ook Struwig, 2005:75-95. Hierdie boek getuig helaas nie van diepgaande teologiese navorsing en besinning nie. Vergelyk verder die kru (en 
Sonder twyfel is die intoggeskiedenis van Israel, en alles wat daarmee gepaard gegaan het, van die heel moeilikste dele in die Bybel soos die onbeantwoorde vraag van Loader aan Tutu ook uitgewys het (p. 184-185). Die naaste aan 'n verklaring van hierdie gebeure is dat die oorloë in hierdie tyd verstaan moet word as gerigsvoltrekking van God oor die sondes van die Kanaäniete (Deut. 9:4). Daarby dra hierdie oorloë 'n hoogs eksepsionele karakter en domineer die vredesmotief in die laaste (veral profetiese) gedeeltes van die Ou Testament (Koole, 1966:50-51). Dit neem 'n sentrale plek in die Nuwe Testament in.

Wat die sogenaamde verwarrende Godsbeelde in die Bybel betref, kan die volgende opgemerk word.

- Indien iemand probleme met die Ou-Testamentiese Godsbeeld ondervind, kan hy/sy noodwendig ook probleme met die NuweTestamentiese Godsbeeld ervaar. Daar is net te veel kontinuïteit tussen die God(sbeeld) van die Ou Testament en die Nuwe Testament om die God van die Ou Testament in teenstelling met die God van die Nuwe Testament te sien. Sowel Jesus as Paulus, asook die ander skrywers van die Nuwe Testament, beskou die God van Abraham, Isak en Jakob as húlle God en Vader (vgl. Hand. 7 en Heb. 11).

- In die Ou Testament self is 'n duidelike kontinuïteit ten opsigte van die Godsbeeld: die sentrale eienskappe wat in die Ou Testament aan God toegedig word, is dat Hy barmhartig, genadig, lankmoedig, vol liefde en trou is - 'n beskrywing wat minstens sewe maal in die Ou Testament herhaal word (Eks. 34:6; Ps. 86:15; Ps. 103:8; Ps. 145:8; Jona 4:2; Joël 2:13; Neh. 9:17), selfs ook ten opsigte van heidene (Jona 4:2). Hierdie beskouing van God word in die Nuwe Testament voortgesit en verdiep (Joh. 3:16; 1 Joh. 4:8). Natuurlik kan God toorn en oordeel, maar dan moet ons hoor dat sy toorn "net vir 'n oomblik duur" maar sy goedheid lewenslank (Ps. 30:6); Hy bly "nie vir altyd kwaad nie" (Jer. 3:12).

ekstreem-eensydige) uitspraak van Dawkins (2007:51): "The God of the Old Testament is arguably the most unpleasant character in all fiction ..." (en dit nadat Dawkins op die vorige bladsy onderneem het: "I shall not go out of my way to offend ..."). Waarom ignoreer Dawkins alles wat oor die liefde en genade van die God van die Ou Testament gesê word? Vir 'n bespreking van die Godsbegrip, vergelyk Durand (1976; 2007). 
- Indien ons moeite het met 'n God (in die Ou Testament) wat oordeel, wat maak ons met 'n God in die Nuwe Testament wat ook oordeel; wat maak ons met die (vir ons byna onvoorstelbare saak van die) laaste oordeel; met lemand wat sê: "Gaan weg van My af ..." (Matt. 25:41)?9

- In die tweede eeu het Marcion ook geredeneer dat die God (van liefde) van die Nuwe Testament iemand totaal anders is as die God (van wraak) van die Ou Testament. Maar Marcion kon dit doen deur met 'n sterk gereduseerde Bybel te werk en sy Bybeltjie baie dun te hou: die Bybel het vir hom net bestaan uit die evangelie van Lukas en die tien ("egte") Pauliniese briewe, en dié is ook weer ligtelik redaksioneel aangepas (Seeberg, 1964:102104; vgl. ook Durand, 2007:36-38, 41-43). Die "Marcionistiese kerk" het egter met die verloop van tyd verdwyn.

\subsection{Oor die Christologie - waar pas Christus in?}

Een van die groot leemtes in Snyman se boek is dat die Christologie (of Jesulogie) nie duidelik uit die verf kom nie, veral soos dit in verband staan met 'n juiste verstaan van die Bybel. Dit is natuurlik waar dat die boek nie oor die persoon en werk van Jesus Christus handel nie, maar ek vind dit, teologies gesien, onmoontlik om oor hermeneutiek en eksegese, Bybellees en Bybelverstaan na te dink sonder om die persoon en werk van Jesus Christus ook indringend ter sprake te bring. Hy is nie net die Woord wat vlees geword het nie (Joh. 1:14), maar ook God se laaste en hoogste en finaalste Woord aan die wêreld (Heb. 1:1-2). Van Hóm het Moses en die profete en die psalms geskryf (Luk. 24:44). Buite Hom om kan geen enkele teks in die Ou en Nuwe Testament werklik verstaan en na sy eintlike sin verklaar word nie. Hý is dié hermeneutiese sleutel van elke Bybelteks. Sonder Hom, en buite Hom om, bly elke Bybelteks 'n geslote boek. Die Bybelteks waarmee ons besig is, sê dit immers self, herhaaldelik, en dit lyk my nie wetenskaplik om hierdie hermeneutiese sleutel nie in spel te bring nie. ${ }^{10}$ Malan, 2008a:82). Vergelyk in hierdie verband die uiteenlopende uitsprake van König (2001:186-188) enersyds: "Die hel as 'n plek ... is sonder meer die grootste probleem in die Christelike geloof ... ons aanvaar dit net in gehoorsaamheid aan die Skrif ..."; en Berkhof (1990:519) andersyds: "In Gods naam hopen wij, dat de hel een louteringsweg zal zijn."

10 Ook in sy artikel oor homoseksualiteit wat in In die Skriflig verskyn het (Snyman, 2006:715-744), ontbreek by Snyman die Christologiese dimensie feitlik heelte- 
Alle goeie teologie, ook hermeneutiek en eksegese, is trinitaries van aard maar Christosentries getoonset. ${ }^{\mathbf{1 1}}$ Wat Bavinck in verband met dogmatiek opmerk, geld eintlik vir alle dissiplines van die teologie:

De leer van Christus is niet het uitgangspunt, maar wel het middelpunt van het gansche dogmatiek. Alle andere dogmata bereiden haar voor of zijn uit haar afgeleid. In haar als het hart der dogmatiek klopt heel het religieus-ethische leven der Christenheid. (Bavinck, 1929:254.)

Die hermeneutiek van die Nederlandse teoloog Greijdanus vind nie veel byval by Snyman nie en dit is waar dat sekere aspekte van sy benadering verouderd is. Tog is daarin nog steeds waardevolle elemente verskuil soos die volgende opmerking (in aansluiting by Bavinck): "Middelpunt van den inhoud der Heilige Schrift is de Heere Christus, of Gods Zelfopenbaring in Hem" (Greijdanus, 1946:50 en 121-123); (vgl. König, 2002:44-46).

Snyman het ongelukkig geen aandag aan hierdie aspek gegee nie, trouens, dit is uit sy boek ook nie duidelik of die klassieke Christologie, waaronder die versoeningsleer, naamlik dat Jesus vir ons sondes gesterf het, nog aanvaar word nie (p. 119). Hy "ervaar die teologie van 'n plaasbekledende Jesus as 'n meganisme wat my eie verantwoordelikheid uiteindelik vernietig" (p. 19). Is die "verhaal van 'n treurige mensheid wat 'n Verlosser nodig het om by God vergiffenis vir sondes te kry" nog vir die skrywer geloofwaardig (p. 187)?

As die Christologie wegval, val die bodem van die teologie uit; die inhoud is dan weg (vgl. Jonker, 1977:185-204; Van de Beek, 1998: 258-263).

mal. Dit is myns insiens ook die grootste enkele probleem met die boek van De Klerk $(1998: 55-57,68,145)$ oor die vreemde, onbegryplike God: die selfbekendmaking van God in Christus is onderbelig en onderbeklemtoon. De Klerk hou egter wel vas aan die belydenis van Christus as Verlosser en dat Hy die skuld en die straf vir die sonde ten volle gedra het (De Klerk, 1998:88, 143).

11 In sy beoordeling van die rapport oor die vrou in die amp wat voor die nasionale sinode van die GKSA in 1988 gedien het, het Snyman (2007:77) nie opgemerk dat die enkele paragrawe wat oor die Christologie handel (GKSA, 1988:512513), en wat deur my geformuleer is, eintlik in spanning verkeer met die res van die rapport nie. Terugskouend gesien, moes ek destyds op grond van die Christologiese argument eintlik 'n minderheidsrapport (ten gunste van die vrou in die amp) ingedien het. 


\subsection{Oor die Pneumatologie - waar pas die Heilige Gees in?}

Daar word deurlopend baie klem gelê op die menslike karakter van die Bybel en die groot inset wat die (subjektiewe) leser moet lewer by die verstaan van 'n Bybelteks. Die skrywer is baie ongemaklik met mense wat agter die Heilige Gees skuil wanneer dit by Skrifinterpretasie kom (p. 32, 68, 141,152). "Eerlike debatvoering is onmoontlik as die Heilige Gees ingespan word om gesag aan argumente te gee. So 'n teologie is outoritêr en nie oorredend nie." (p. 118.)

Dit is natuurlik waar dat die Heilige Gees nie as 'n goedkoop ontsnappingsmeganisme gebruik behoort te word wanneer 'n Bybelteks verstaan moet nie word (p. 54). Die werk van die Gees mag egter ook nie op nonaktiwiteit geplaas word by die verstaan van die Bybel nie.

Ek vind die benadering van Snyman in hierdie verband onwetenskaplik. Indien die (Bybel-)teks waarmee jy werk self sê dat méér as rasionele nadenke nodig is om die diepste intensie daarvan te verstaan, dan is dit onaanvaarbaar om hierdie "meer as" (dus die werk van die Heilige Gees) eenvoudig te ignoreer.

Paulus oordeel byvoorbeeld dat 'n mens nie (die geskrifte van) Moses sonder die Gees - wat van Christus getuig - kan verstaan nie (2 Kor. 3:12-17; vgl. 1 Kor. 2:13-16). Sonder dat dit aan iemand van Bo gegéé word, kan niemand bely dat Jesus die Messias is (Matt. 16:17), dat Jesus die Here is (1 Kor. 12:3) en dat die evangelie van die kruis die (enigste) ware evangelie is nie (Gal. 1:11). Dit is onmoontlik om hierdie hoë belydenis aangaande Jesus van Nasaret "van onder" uit te dink en uit te spreek.

Van Kuitert (1974:28) is die bekende uitdrukking dat "alle spreken over boven komt van beneden, ook de uitspraak dat iets van boven komt", maar daarmee is nog geen bewys gelewer dat 'n uitspraak nie inderdaad van bo/Bo ingegee kon gewees het nie. In hierdie verband het Greijdanus (1946:40-41) weereens 'n sinvolle (en nogal uitdagende) opmerking gemaak. Hy voer aan dat die gawe van die "Skrif alleen", hoe onmisbaar en heerlik dit ook al mag wees, "nie genoeg is nie", omdat ons 'n behoefte het aan die vernuwing deur die Heilige Gees wanneer ons die Skrif verklaar.

Alle hermeneutiese beginsels kan en mag ingespan word om 'n Bybelteks goed te verstaan, maar dit is onwetenskaplik en onspiritueel 
om die verligtende werk van die Gees van God in hierdie proses te ignoreer. ${ }^{12}$ As ons die belydenis laat vaar dat die Gees die kerk in die hele waarheid lei (ten opsigte van fundamentele sake; Joh. 16:13), dan het ons in oewerlose subjektivisme verval.

\subsection{Hoe verkry ons kennis? Oor epistemologie}

Geen teologie funksioneer sonder 'n bepaalde epistemologie soos skeptisisme, rasionalisme, positivisme, ensovoorts nie. Snyman se hele boek is een groot verset teen wat hy beskou as objektivisme, positivisme, fundamentalisme en naïewe realisme. Self kies hy vir subjektivisme en relasionalisme (as waarheidsbeskouing), want daar bestaan geen vasstaande objektiewe waarhede nie (p. 5859). 13

Hierdie standpunt word egter deur 'n paar probleemvrae gedruk. Allereers is dit selfweersprekend. Dit is bedoel om 'n waarheidsuitspraak te wees, maar volgens die benadering van die skrywer bestaan daar geen vaste waarhede nie.

Tweedens veronderstel dit dat die relasionele waarheidsbeskouing die beste resultate lewer, maar hierdie waarheidsbeskouing is reeds aan skerp kritiek onderwerp (vgl. bronverwysings by Van Wyk, 1989:25).14 Daar bestaan trouens 'n hele reeks waarheidsteorieë

12 Vergelyk in hierdie verband die instruktiewe besinning oor "Heilige Gees en hermeneutiek" deur Veenhof (2005:298-310). Vergelyk verder ook Jonker (1981: 50-58).

13 Vergelyk in hierdie verband die (kritiese) boek van Kennedy (2006) wat deur die Nuwe Hervorming hoog aangeskrewe is. Die klassieke Christelike geloof word hierin dermate bevraagteken dat daar van vaste sekerhede (waarhede) byna geen sprake meer is nie. Al sekerheid wat bestaan, is dat daar uiteindelik geen sekerhede (waarhede) bestaan nie. Desondanks laat die skrywer die indruk by die leser dat hy nog ten gunste van "God" en "Jesus as voorbeeldige mens" kies. Maar op grond waarvan doen hy dit? Is die logiese konsekwensie van die radikaal-kritiese teologie nie uiteindelik dié van D.F. Strauss wat die Christelike geloof afgelê het en vir ateïsme/agnotisisme gekies het nie (p. 154)? Kennedy het ook nie indringende aandag bestee aan die groot teoloë van die twintigste eeu nie, byvoorbeeld Barth, Bonhoeffer, Moltmann en Pannenberg. Het hy ooit Augustinus deeglik bestudeer? Vergelyk hierteenoor die boek van McGrath (2005) en sy opmerkings oor die postmodernisme en waarheid (p. 255-263).

14 In sy studie oor Skrifbeskouing aanvaar Malan (2008a) die relasionele waarheidsbeskouing kritiekloos en vind hy ook sterk aansluiting by Bultmann se ontmitologiseringsprogram (Malan, 2008a:37-39,54) - soos hy tewens reeds vroeër (kritiekloos) gedoen het (Malan, 2000). In so 'n benadering is daar nie meer sprake van die liggaamlike opstanding van Jesus nie (Malan, 2008a:82) soos ook by Schutte (2006) die geval is. (By Malan speel die begrip openbaring 
(Van Wyk, 2001:86-91), waarvan die (postmoderne) relasionele waarheidsbeskouing maar een is en as teorie nie noodwendig die mees vrugbare nie. "Die waarheid" is trouens multidimensioneel (Van Wyk, 2001:92-100). Die groot vraag is of die relasionele waarheidsbeskouing nie tog ons kennis in so 'n mate relativeer dat ons onvermydelik in relativisme en uiteindelik in skeptisisme teregkom nie (Van Wyk, 1989:24-25)? Dit is waar: meer as ooit tevore besef ons vandag die onafheid, voorlopigheid en beperktheid van alle menslike kennis. Dit sou egter verkeerd wees om uit die beperktheid van ons kennis te konkludeer tot die onegtheid daarvan.

Die skrywer merk tereg op dat die verswyging van ons filosofiese raamwerke 'n groot probleem is (p. 68), maar die vraag waarmee ek deurgaans by die lees van die boek geworstel het, is: presies van watter vooronderstellings Snyman self uitgaan en waar kry hy daardie presupposisies en op grond waarvan kies hy daarvoor?

\subsection{Die groot voorbeeld: fundamentalisme is die bron van apartheid}

In die boek van Snyman word herhaaldelik na apartheid verwys as 'n voorbeeld van hoe 'n klassieke Bybelverstaan die kerk en teologie in 'n impasse laat beland het.15 Hierdie voorbeeld is slegs gedeeltelik relevant - meer aktueel is die verwysings na die vrou in die amp en homoseksuele persone.

Dit is natuurlik waar dat kerk en teologie die Bybel op 'n skaamtelose wyse misbruik het ten opsigte van die teologiese regverdiging

geen rol nie.) Die onbegryplike is dat terwyl die ontmitologiseringsparadigma van Bultmann in Duitsland feitlik geen aanhangers het nie, dit tans in Suid-Afrika sterk voorgestaan word. Malan $(2008 a: 46,57,71,74)$ sluit ook by Barth aan: die Bybel is nie die Woord van God nie, maar moet telkens weer die Woord van God word. Malan se standpunt vertoon groot ooreenkomste met dié van die Nuwe Hervorming en daarom is dit verbasend om in die voorwoord te verneem dat die kommissie van die algemene kerkvergadering van NHKA "met instemming kennis geneem het van hierdie publikasie". Het die kommissie die publikasie deeglik genoeg bestudeer? Vergelyk ook die positiewe boekresensie van W.C. van Wyk in Die Hervormer (2008:7). Selfs by 'n kritiese teoloog soos Berkhof (1990:305) speel die opstanding (opwekking) van Jesus 'n deurslaggewende rol: "Daarom staat en valt het christelijk geloof met de opstanding." Vergelyk hier ook die (omstrede) boek van Müller (2006) oor die opstanding, en vir die teendeel (Gaum, 2004; 19 van die 20 gesprekke).

15 Vergelyk hier ook Carroll (2000:51) wat van oordeel is dat "the Bible is an unsafe book from which to do politics or social engineering in contemporary society". Die Bybel bied immers sowel bevrydende as onderdrukkende modelle en moet dus uiters krities gelees word. 
van apartheid. Daarmee is nog nie bewys dat, omdat die Bybel in hierdie geval totaal misbruik is, ook die klassieke belydenis oor die Bybel noodwendig foutief is nie. Dit is nie (net) 'n foutiewe Skrifbeskouing wat tot 'n foutiewe politieke beskouing (kan) lei nie (bv. verabsoluteerde nasionalisme), maar dis veel eerder 'n ideologiese verblinding waarmee ons hier te doen het - en in kerk en teologie te doen gehad het. ' $n$ Kritiese Skrifbeskouing bied geen outomatiese waarborg teen ideologiese verblinding nie. 'n Ortodokse beskouing van die Bybel hoef nie noodwendig tot 'n (foutiewe) konserwatiewe politiek (apartheid) te lei nie. ${ }^{16}$

Dit was die ideologie van Afrikanernasionalisme (later-imperialisme) wat mense verblind het om die ware evangelie in sy volle reikwydte raak te sien. Vandag is dit Afrika-nasionalisme (Afrikanisme) wat mense (ook kerkmense) verblind om ons samelewing op 'n regverdige en verantwoordelike wyse te bestuur. Elke ideologie verblind en ondermyn 'n samelewing en maak dat ons die Bybel verkeerd lees en verstaan.

Ook in die kritiese teologie is daar voorbeelde van die ondersteuning van konserwatiewe (nasionalistiese) politiek. Die klassieke voorbeeld hier is die groot Duitse dogmahistorikus Adolf von Harnack.17 Von Harnack was 'n kritiese teoloog maar tog iemand wat 'n dokument (saam met 92 ander intellektuele) onderteken het waarin hy (hulle) die nasionalistiese oorlogspolitiek van keiser Wilhelm II in 1914 ondersteun het. Hierop het die bekende Switserse teoloog Karl Barth gereageer met: "An ihrem 'ethischen Versagen' zeigte sich 'dass auch ihre exegetischen und dogmatischen Voraussetzungen nicht in Ordnung sein könnten'” (Busch, 1976:93). Hierna het Barth afskeid geneem van die liberale teologie van sy tyd. Barth (en Bonhoeffer) het juis op grond van hulle "ortodokse" teologie Nazisme teengestaan. In hierdie verband het die "ortodokse" teologie van Barth (al was hy voorstander van 'n aktualistiese Skrifbeskouing) veel beter resultate gelewer as die Skrifkritiese benadering van Von Harnack.

16 Vergelyk in hierdie verband die veelseggende opmerking van Helen Zille (tans leier van die DA) in 'n gesprek met Max du Preez: "Ek is 'n diep godsdienstige mens - die ironie is, hoe dieper konserwatief godsdienstig jy word, hoe meer liberaal word jy in die politiek, want jy oordeel nie mense nie." (Du Preez, 2004:22.) Vergelyk De Gruchy en De Gruchy (2004) vir 'n breedvoerige bespreking van die kerkstryd oor apartheid in Suid-Afrika.

17 Vergelyk die volgende uitspraak van Dietrich Bonhoeffer: "Dogmatisch gesehen war Harnack ein Irrlehrer" (aangehaal deur Rothuizen, 1969:193). 
Nog ' $n$ voorbeeld wat in hierdie verband genoem kan word is die groot Duitse kritiese teoloog Rudolf Bultmann (by wie die Nuwe Hervorming sterk aansluiting vind). Hy is deur kritici erg verkwalik omdat hy (tydens die Tweede Wêreldoorlog waartydens ongeveer 60 miljoen mense gedood is) polities onbetrokke en godsdienstig piëtisties was (Moltmann, 1989:76). Die oomblik toe Duitsland Rusland binnegeval het, het Bultmann 'n kerkdiens gelei en nóg in die preek nóg in die gebed enigsins na hierdie gebeure verwys (Van de Beek, 1994:85). Sy kritici kon dus vra of hy hom nie eerder (soos Bonhoeffer) teen die Nazisme van Hitler moes verset het nie in plaas daarvan om hom met die ontmitologisering van die Nuwe Testament (in 1941!) besig te hou. Vir Bultmann was geloof klaarblyklik "a private matter" wat niks met politiek te make het nie (Moltmann, 2008:50). Die vraag is daarom tereg gestel of die kritiese teologie van Bultmann hoegenaamd enige politieke relevansie besit (Zahrnt, 1967:264-265).

Ek dink in hierdie verband ook aan die persepsie dat teoloë van die NHKA 'n (bepaalde vorm van) kritiese teologie beoefen, maar tog 'n konserwatiewe politiek (apartheid) ondersteun het. By die jonger hervormde teoloë word tans veel kritieser oor die verhouding kerk en volk (en die volkskerk) gedink. ${ }^{18}$

Ook in Suid-Afrika is daar voorbeelde waar 'n ortodokse teologie gelei het tot 'n maatskappykritiese stellingname. In hierdie verband kan verwys word na die begaafde NG-teoloog Willie Jonker, wat apartheid lewenslank juis op grond van sy "ortodokse" teologie verwerp het (vgl. Jonker, 1998). 'n Mens sou ook na Beyers Naudé kon verwys, maar sy kritiek was, anders as by Jonker, meer van buite-af as van binne-uit (die NGK). 19

As ek na myself mag verwys: ek het as ondersteuner van apartheid begin, maar algaande meer en meer krities daarteenoor ingestel geraak om uiteindelik in 1979 as (dormante) lid uit die NP te bedank om my kritiek (intern) veral in geskrifte en voordragte ter sprake te bring (asook vele insette by sinodebesluite). Helaas nie hard genoeg nie, vandaar die openbare skuldbelydenis van 1997 saam met drie

18 Vergelyk Buitendag (2006:792): "[W]e honestly confess that apartheid is indeed a sin and that any attempts to justify it in accordance with the Bible is nothing less than a heresy."

19 Een van die sterkste uitsprake teen die (teologiese) regverdiging van apartheid is te vind in die Belydenis van Belhar (1986). Hierdie belydenis maak gebruik van klassieke teologiese, Christologiese en ekklesiologiese uitgangspunte. 
ander (Van Wyk, 1998:365-367). Dit alles op grond van ortodokse teologies-etiese oorwegings, naamlik dat apartheid in stryd is met die beginsels van die koninkryk van God en die evangelie van Jesus Christus - beginsels soos naasteliefde, vryheid, versoening en geregtigheid.

Snyman bring die Gereformeerde teoloog Totius dikwels ter sprake as voorbeeld van iemand wat vanuit sy gereformeerde oortuiging apartheid onkrities ondersteun het (p. 27, 74-75, 79-81, 112, 162). Daar word selfs genoem dat "sover ek weet, is Totius se rassistiese teologie nog nie krities onder die loep geneem nie" (p. 27). Tog het ek reeds in verskeie artikels (soms baie) krities op Totius se apartheidsdenke ingegaan - die uitgebreidste in my geskrif Homo Dei (Van Wyk, 1993:41-42), sodat ek selfs daarvan beskuldig is dat my bespreking van Totius "'n simplistiese, ongekwalifiseerde vorm van etikettering" is (D'Assonville, 1994:270) - en waarop ek in 'n boekresensie (krities) geantwoord het (Van Wyk, 1994:681). Ek het in my kritiek op Totius gebruik gemaak van wat in die filosofie bekend staan as die transendentale metode: Totius was in sy benadering van apartheid nie getrou aan sy eie uitgangspunte nie. 'n Mens kan tog nie enersyds beweer dat Christus die sentrum van die Godsopenbaring is, 20 maar andersyds die Christologie in die politiek onderspeel en slegs van 'n skeppingsteologie gebruik maak nie.

Skynbaar is geen - klassieke of kritiese - teologie opgewasse teen die geweldige suigkrag van 'n (politieke) ideologie nie. Dit is uiteindelik net die Gees van God wat 'n mens se oë kan oopmaak om die gevare van ideologiese verblinding te herken.

Snyman verwys dikwels na die foutiewe hermeneuse en eksegese wat die debatte rondom die vrou in die amp en homoseksuele persone ten grondslag lê. Ook in hierdie verband kan dieselfde gesê word. Dit is moontlik om aan die hand van 'n goeie klassieke "ortodokse" benadering te konkludeer dat vroue wél in die ampte mag dien (Wentsel, 1998:227-284; Wentsel, 2006:482). Dit is ook moontlik om vanuit 'n "ortodokse" beskouing te konkludeer dat die moderne homoseksuele probleem iets anders is as die homoseksualiteit wat deur die Bybel afgewys word - vir die Ou Testament kan verwys word na S.D. Snyman (2006:968-981) en vir die Nuwe Testament

20 Vergelyk Du Toit (1941:42): "Die Bybel is die Godsopenbaring. Dit ontvou vir ons die Goddelike plan van verlossing soos gesentraliseer in Jesus Christus, die Middelaar van God en die mense." 
na A.B. du Toit (2007:161-171). S.D. Snyman bevind dat die homoseksuele persone waarna in Levitikus (en die Ou Testament) verwys word, op manlike heteroseksuele persone dui wat in homoseksuele praktyke (veral in familieverband) betrokke geraak het; Du Toit argumenteer dat die onnatuurlike relasies waarna Paulus in Romeine 1 verwys, op heteroseksuele mans en vrouens dui wat hulle aan homoseksuele praktyke skuldig gemaak het.21

\subsection{Etiek van deursigtigheid}

Die skrywer lê klem op die begrip eerlikheid (p. 131) en in die Christelike etiek speel dit 'n belangrike rol. Ook in die beoefening van teologie is dit baie belangrik.

Dit is moontlik dat 'n teoloog tot radikaal ander insigte kan kom as wat in die klassieke ekumeniese en reformatoriese belydenisskrifte verwoord is. Ek dink in hierdie verband aan die standpunte van die Nuwe Hervorming waarvan Durand (2005:107) konkludeer dat ons hier met 'n "alternatiewe geloof" te doen het. Om in sulke omstandighede dan nog voor te gee dat ons nog met "dieselfde geloof" te doen het, bring etiese beginsels soos eerlikheid, openhartigheid, deursigtigheid en integriteit sterk in die gedrang. 22

'n Teoloog het die vryheid om tot ander insigte te kom, maar as hy/sy tot radikaal ander insigte gekom het wat die wese van die evangelie raak (en verander) soos dit wêreldwyd verstaan en geglo word (vgl. die regula fidel), moet hy/sy die moed van sy/haar oortuiging hê om dit aan die geloofsgemeenskap waarby hy/sy betrokke is, bekend te maak. Daarop behoort dan oor hierdie sake 'n verantwoordelike gesprek plaas te vind. Dit kan dan gebeur dat die een vir die ander mag sê, soos Paulus vir Petrus: As jy dít of dát doen of voorstaan, wyk jy af van die evangeliese waarheid (Gal. $2: 14)$.

Ek wil nie graag misverstaan word as 'n kru voorstander van 'n restourasie-teologie nie: dis moontlik - en noodsaaklik - om ou waarhede in nuwe kontekste nuut te verwoord (in die sin van: nove

21 Vanselfsprekend stem alle navorsers nie hiermee saam nie, vergelyk slegs Van Rensburg (2006) en Potgieter (2007).

22 Malan (2008a:35, 54, 85) werk hier met twee interpretasiemodelle, een vir die (kritiese) teoloog en een vir die ("naïewe") lidmaat. Myns insiens kan so 'n dubbele verstaan van die evangelie (byvoorbeeld oor die opstanding; Malan, 2008a:82) nie konfessioneel verantwoord word nie. 
dicere sed non nova), maar as dit skielik nuwe waarhede word wat weinig kontinuïteit met die ou waarhede bevat, kom die vraag na 'n alternatiewe geloof ter sprake.23 As voorbeeld dink ek in hierdie verband aan die wyse waarop die Nuwe Hervorming die kruis en liggaamlike opstanding van Jesus radikaal herinterpreteer om by iets totaal anders uit te kom as wat die evangeliste en apostels aan ons oorgedra het (vgl. Muller, 2002).

\section{Konkludering}

Snyman het sonder twyfel 'n eerlike en uitdagende boek aan ons voorgelê wat nog wye bespreking gaan uitlok. ${ }^{24}$ Dat hy kernprobleme aangeraak en blootgelê het, staan vas. Hy het my egter nie oortuig dat sy voorstel 'n beter oplossing bied as die klassieke benadering tot die verstaan van die Bybel nie - mits dit natuurlik korrek hanteer word.25 Een van die grootste leemtes in die boeiende betoog van Snyman is dat hy nie ondubbelsinnig aangetoon het waarom die (boodskap van die) Bybel hoegenaamd belangrik en noodsaaklik is nie.

23 Vergelyk in hierdie verband ook die reaksie van Vergeer (1993) op vroeëre standpunte van Snyman. Vergelyk ook die totaal ander aanslag en toonaard van die boek van Smit (2006) oor die Skrifleer. Vir 'n weergawe van die klassiek gereformeerde standpunt, vergelyk Jordaan (2004). Jordaan (2004:263) aanvaar wel die moontlikheid van "oneffenhede" in die Bybel ten opsigte van byvoorbeeld historiese en geografiese gegewens.

24 Vergelyk hier die volgende (redelik onkritiese) boekresensies: Lombaard (2008: 11), Van Wyk (2008:7), Malan (2008b:1106-1108).

25 Vergelyk. in hierdie verband die kritiese oordeel van 'n ateïstiese filosoof oor die liberale teologie:

Die ateïs betoog dat die Christendoktrines met rede [die menslike verstand - JHvW] in konflik verkeer en daarom verwerp moet word; die liberale teoloog betoog dat die Christendoktrines met rede in konflik verkeer en daarom geherinterpreteer moet word ... Maar interpretasie in die hande van die moderne teoloog verwring die Christengeloof tot 'n groteske karikatuur van wat dit oor die afgelope negentien eeue was. Wat dit egter steeds nie doen nie, is om rede en Christengeloof te versoen. (Pellencin, 2007:129.)

In 'n voetnoot word verder gestel: "Dit is by die beskouing van kwessies soos hierdie wat ons wonder hoe die liberale Christen van 'n nie-Christen verskil." (Pellencin, 2007:129.) 
Ons as (post)moderne mense verkeer baie meer in die greep van ('n naïewe) rasionalisme as wat ons meestal besef. 26 Dit is in 'n sekere sin onvermydelik, maar daarom nog nie goed te keur nie. Ons almal - ortodokse en kritiese Christene - moet voortdurend bewus wees van die suigkrag wat rasionalisme (en indidividualisme) veral sedert die Aufklärung van die agtiende eeu op ons teologie uitoefen. Daarmee wil ek sê dat indien ons die begrip openbaring as (onopgeefbare) element van ons epistemologie laat vaar, ons kort voor lank nie meer met teologie besig is nie, maar het ons onbewus na die terrein van (spekulatiewe) filosofie oorgegly en op die gebied van vrye spekulasie tereg gekom.

In watter rigting moet 'n oplossing vir 'n juiste Skrifverstaan en Bybellees dan gesoek word? Self ag ek die volgende rigtingwysers belangrik:

- In die Christelike geloofstradisie geniet die Bybel epistemologiese voorrang as betroubare en normatiewe teks bo enige ander teks. Dít, nie op grond van 'n erkenning van formele Skrifgesag nie, maar omdat die inhoud van die Bybel oorredend, bevrydend en rigtinggewend is.

- Sonder om in 'n sacrificium intellectus te verval, moet bely word dat die verligtende werk van die Heilige Gees onmisbaar is by die verstaan van die boodskap van die Bybel. Alle bruikbare verstaansreëls mag ingespan word om 'n teks (in konteks) te verstaan, maar die werk van die Gees bly onmisbaar.

- Teologiebeoefening vind meestal individueel plaas, maar daar moet gewaak word teen individualisme. Uiteindelik kry ons 'n begrip van die wydte en verte en hoogte en diepte van die liefde van Christus "saam met al die gelowiges" (Ef. 3:18; Hand. 15; vgl: Smit, 2006:108,164). Die ekumene speel 'n belangrike rol by Skrifverstaan (juis buitelandse gereformeerde kerke het telkens gewaarsku teen die dwaling van apartheid).

Ek is deeglik daarvan bewus dat ek van 'n vorm van "naïewe realisme" verdink word, vergelyk Van Deventer (2005:753): "Myns insiens ontkom Van Wyk se bydrae [oor skepping en evolusie], ten spyte van die belangrike insigte wat dit bied, nie aan 'n vorm van naïewe realisme nie ..." Vir 'n bespreking van my studie oor Die Woord is waardevol (1989), vgl. Deist (1991:930-935). Deist (1991:930-931) merk die volgende op: "Van Wyk's rejection of reformed orthodoxy's view of Scripture already indicates a sharp departure of earlier GK views"; vgl. ook sy vriendelike opmerking: "In terms of the classical or orthodox Reformed view of Scripture, Van Wyk's articulate exposition indeed makes pleasant reading." (Deist, 1991:933.) 
- Teoloë behoort altyd bewus te wees van wat genoem word kenteoretiese voorlopigheid, wat beteken dat al ons kennis (ook teologiese) 'n voorlopige karakter dra. Ons moet egter nie uit die beperktheid van ons kennis tot die onegtheid daarvan konkludeer nie.

- Teoloë moet ook voortdurend daarmee rekening hou dat (dikwels onbewuste) vooronderstellings 'n groot rol by Skrifinterpretasie speel en daarom behoort hierdie vooronderstellings altyd geartikuleer en desnoods gekritiseer te word.

- Goeie teologie behoort altyd in diens te staan van die uitbreiding van die kerk van Christus en die koms van die koninkryk van God. Enige teologie wat nie die geloof van gelowiges versterk, die evangelieverkondiging bevrug en die profetiese getuienis van die kerk bevorder nie, is swak teologie.

\section{Geraadpleegde bronne}

BAVINCK, H. 1929. Gereformeerde dogmatiek. DI. 3. Kampen: Kok.

BERKHOF, H. 1990. Christelijk geloof: een inleiding tot de geloofsleer. Nijkerk: Callenbach.

BUITENDAG, J. 2006. Coming in from outside: a crucial event in the history of ecumenism of the Nederduitsch Hervormde Church. HTS teologiese studies, 62(3):787-817.

BUSCH, E. 1976. Karl Barths Lebenslauf: nach seinen Briefen und autobiographischen Texten. München: Kaiser.

CARROLL, R.P. 2000. (South) Africa, Bible, criticism: rhetorics of a visit. Journal of theology for Southern Africa, 108:39-53.

CRAFFERT, P.F. 2002. Wat sê die Bybel regtig oor ... die hel? Pretoria: Unisa.

D'ASSONVILLE, V.E. 1993. Dit is Totius: J.D. du Toit 1977-1953. Lynnwoodrif: Marnix.

DAWKINS, R. 2007. The God delusion. London: Bantam/Black Swan.

DE GRUCHY, J.W. \& DE GRUCHY, J. 2004. The church struggle in South Africa. 25th Anniversary edition. London: SCM.

DE KLERK, W. 1998. Die vreemde God en sy mense. Kaapstad: Human \& Rousseau.

DEIST, F.E. 1986. Kan ons die Bybel dan nog glo? Pretoria: Van Schaik.

DEIST, F.E. 1991. The Bible in discussion: three recent South African publications on Scripture. Hervormde teologiese studies, 47(4):930-949.

DEIST, F.E. 1994. Ervaring, rede en metode in Skrifuitleg: wetenskapshistoriese ondersoek na Skrifuitleg in die Ned. Geref. Kerk 1840-1990. Pretoria: RGN.

DU PREEZ, M. 2004. Helen Zille oor skole, godsdiens en Tony Leon: politiek. Insig, 15(194):20-22.

DU TOIT, A.B. 2007. Maar die grootste hiervan is die liefde - oor homoseksualiteit in Romeine 1. (In Vos, C. \& Human, D., reds. Liefde is die grootste: oor erotiek en seksualiteit. Pretoria: Protea Boekhuis.) 
DU TOIT, J.D. 1941. Die Bybel is die Woord van God. Stellenbosch: Pro Ecclesia.

DURAND, J.J.F. 1976. Die lewende God: wegwysers in die dogmatiek. Pretoria: N.G. Kerkboekhandel.

DURAND, J.J.F, 2005. Doodloopstrate van die geloof: 'n perspektief op die Nuwe Hervorming. Stellenbosch: Rapid Access.

DURAND, J.J.F. 2007. The many faces of God: highways and byways on the route towards an orthodox image of God in the history of Christianity from the first to the seventeenth century. Stellenbosch: Sun Press.

GAUM, F., red. 2004. Gesprekke oor ... die opstanding van Jesus uit die dood. Kaapstad: Ex Animo.

GEREFORMEERDE KERKE IN SUID-AFRIKA, 1942. Handelinge van die 27e sinodale vergadering van die Gereformeerde gemeentes in Suid-Afrika. Aliwal-Noord.

GEREFORMEERDE KERKE IN SUID-AFRIKA, 1988. Handelinge van die drie en veertigste nasionale sinode: die Gereformeerde Kerke in Potchefstroom: Suid-Afrika. Potchefstroom.

GKSA

kyk GEREFORMEERDE KERKE IN SUID-AFRIKA

GREIJDANUS, S. 1946. Schriftbeginselen ter Schriftverklaring en historisch overzicht over theorieën en wijzen van Schriftuitlegging. Kampen: Kok.

HEYNS, J.A. 1973. Brug tussen God en mens: oor die Bybel. Pretoria: NG Kerkboekhandel.

JONKER, W.D. 1977. Christus, die Middelaar. Pretoria: NG Kerkboekhandel.

JONKER, W.D. 1981. Die Gees van Christus. Pretoria: NG Kerkboekhandel.

JONKER, W.D. 1998. Selfs die kerk kan verander. Kaapstad: Tafelberg.

JORDAAN, G.J.C. 2004. Gereformeerde teologie in die spervuur tussen fundamentalisme en anti-fundamentalisme. (In De Boer, A. \& d'Assonville, V.E., jr., reds. Ad fontes: historiese, teologiese en wetenskaps-filosofiese studies binne reformatoriese kader. Festschrift vir Ludi Schulze. Acta theologica, supplementum 5.)

JORDAAN, J. 2007. Homoseksualiteit: 'n Skrifgefundeerde perspektief. Vereeniging: CUM.

KENNEDY, P. 2006. A modern introduction to theology: new questions for old beliefs. London: Taurus.

KÖNIG, A. 2001. Fokus op die 300 geloofsvrae wat mense die meeste vra: 'n verwysingsgids vir elke huis. Wellington: Lux Verbi.BM.

KÖNIG, A. 2002. Ek glo die Bybel - ondanks al die vrae. Wellington: Lux Verbi.BM.

KOOLE, J.L. 1966. Bijbelse bezinning. (In Bavinck, H. et al. Christendom en oorlog: gereformeerde stemmen over het oorlogsvraagstuk. Kampen: Kok.)

KUITERT, H.M. 1974. Zonder geloof vaart niemand wel: een plaatsbepaling van Christendom en kerk. Baarn: Ten Have.

LOMBAARD, C. Wit, waaghalsig en welwillend. Kerkbode, 11, 8 Feb 2008.

MALAN, G. 2000. Bultmann se ontmitologiseringsprogram herwaardeer. Hervormde teologiese studies, 56(4):1107-1118.

MALAN, G. 2008a. Om die Bybel (beter) te verstaan. Pretoria: Sentik.

MALAN, G. 2008b. Boekbespreking. Hervormde teologiese studies, 64(2): 1106-1108. 
McGRATH, A. 2005. Bruggen bouwen: over het effectief doorgeven van het Christelijk geloof. Vert. door M.J. Stengholt. Kampen: Voorhoeve.

MOLTMANN, J. 1989. Wat is theologie? De weg van de theologie in de twintigste eeuw. Baarn: Ten Have.

MOLTMANN, J. 2008. A broad place: an autobiography. Minneapolis: Fortress.

MOSALA, I.J. 1989. Biblical hermeneutics and black theology in South Africa. Grand Rapids: Eerdmans.

MÜLLER, J. 2006. Opstanding. Wellington: Lux Verbi.B.M.

MULLER, P., red. 2002. Die Nuwe Hervorming. Pretoria: Protea Boekhuis.

NÜRNBERGER, K. 2002. Theology of the Biblical witness: an evolutionary approach. Münster: Lit Verlag.

PELLENCIN, A.L. 2007. Ateïsme: die saak teen God. Pretoria: Publiself.

POTGIETER, J. 2007. Homoseksualiteit: 'n Skrifgefundeerde perspektief. Vereeniging: CUM.

POTGIETER, P.C. 1990. Skrif, dogma \& verkondiging. Kaapstad: Lux Verbi.

ROTHUIZEN, G. TH. 1969. Aristocratisch Christendom: over Dietrich Bonhoeffer. Kampen: Kok.

SCHUTTE, P.J.W. 2006. The resurrection of Jesus: what's left to say? Hervormde teologiese studies, 62(4):1513-1526.

SEEBERG, R. 1964. Text-book of the history of doctrines. Vol. 1. Grand Rapids: Baker.

SMIT, D. 2006. Neem, lees! Hoe ons die Bybel hoor en verstaan. Wellington: Lux Verbi.BM.

SNYMAN, G. 2006. Homoseksualiteit en tydgerigtheid: 'n etiek van Bybellees? In die Skriflig, 40(4):715-744.

SNYMAN, G.D. 2007. Om die Bybel anders te lees: 'n etiek van Bybellees. Pretoria Griffel Media.

SNYMAN, S.D. 2006. Help Levitikus 18:22 en 20:13 die (NG) kerk in die debat oor homoseksualiteit? Old Testament essays, 3:968-981.

SPANGENBERG, I. 1998. Perspektiewe op die Bybel: God se Woord in mensetaal. Pretoria: Van Schaik.

STRUWIG, E. 2005. Fynskrif: dié dinge wat die kerk nie wil hê jy moet weet nie. Parklands: Whynotbooks.

VAN DE BEEK, A. 1998. Jezus Kurios: de Christologie als het hart van de theologie. Kampen: Kok.

VAN DE BEEK, B. 1994. Van verlichting tot verduistering? Theologen vanaf 1800. Nijkerk: Callenbach.

VAN DER DUSSEN. P.E. 2006. Kerk van Christus - waarheen? Reformasie teenoor transformasie. Lyttelton: Rotsvas.

VAN DER WALT, S.J. 1989. Die roeping van die kerk ten opsigte van etiese vraagstukke in die samelewing met toepassing op uitsprake van sinodes van die Gereformeerde Kerke in Suid-Afrika. Potchefstroom: PU vir CHO. (Th.D.-verhandeling.)

VAN DER WATT, J., JOUBERT, S., DU RAND, J. \& NAUDÉ, P. 2002. Hoe lees ons die Bybel? 'n Soeklig op die rol van die Woord en hoe om dit te vertolk in hedendaagse tye. Vereeniging: CUM.

VAN DEVENTER, H.J.M. 2005. "In die begin ...": oor vertrekpunte en die verstaan van tekste. Koers, 70(4):749-773.

VAN HUYSSTEEN, W. \& DU TOIT, B. 1982. Geloof en Skrifgesag: 'n analise van die Skrifgesagprobleem na aanleiding van die rapport "God met ons". Pretoria: NG Kerkboekhandel. 
VAN NIEKERK, A.A. 2005. Geloof sonder sekerhede: besinning vir eietydse gelowiges. Wellington: Lux Verbi.B.M.

VAN NIEKERK, A.A. 2007. Oor tradisie, hermeneutiek en wetenskap: mistastings in Sakkie Spangenberg se lesing van Geloof sonder sekerhede: besinning vir eietydse gelowiges. Nederduitse Gereformeerde teologiese tydskrif, 48(3 \& 4):674-685.

VAN RENSBURG, F.J. 2006. Die tydgerigtheid van die Bybel en die etiek van Bybellees: respons op die artikel van Gerrie Snyman. In die Skriflig, 40(4): 745-769.

VAN WYK, J.H. 1989. Die Woord is waardevol: 'n dogmatiese besinning oor die reformatoriese Skrifbeskouing. Potchefstroom: $\mathrm{PU}$ vir $\mathrm{CHO}$.

VAN WYK, J.H. 1993. Homo Dei: 'n prinsipiële besinning oor enkele mensbeskouings, waaronder dié van Calvyn. In die Skriflig, 27, Supplementum 1.

VAN WYK, J.H. 1994. Boekresensie. In die Skriflig, 28(4): 679-693.

VAN WYK, J.H. 1998. Etiek in eenvoud: gesprekke oor morele vraagstukke. Potchefstroom: Potchefstroomse Teologiese Publikasies.

VAN WYK, J.H. 2001. Etiek en eksistensie - in koninkryksperspektief. Potchefstroom: Potchefstroomse Teologiese Publikasies.

VAN WYK, W.C. 2008. Die Bybel in konteks. Die Hervormer, 101(6):7

VEENHOF. J. 2005. Vrij gereformeerd. Verzamelde artikelen bezorgd door Dirk van Keulen et al. Kampen: Kok.

VELEMA, W.H. 1997. De verhoudingen van openbaring en ervaring toegespits op de ethiek. In die Skriflig, 31(1 \& 2):107-121.

VERGEER, W. 1993. Teologie en kenteorie: 'n reaksie op die artikels van Gerrie Snyman. In die Skriflig, 27(4):563-582.

WENTSEL, B. 1998. De Heilige Geest, de kerk en de laatste dingen: de kerk als het saamhorige volk Gods. Kampen: Kok. (Dogmatiek deel 4B.)

WENTSEL, B. 2006. Hij-is-er-bij: handboek Bijbelse geloofsleer. Deel 2. Kampen: Kok.

WEST, G.O. 1991. Biblical hermeneutics of liberation: modes of reading the Bible in the South African context. Pietermaritzburg: Cluster.

ZAHRNT, H. 1967. Wachtend op God: de Duitse protestantse theologie in de twintigste eeuw. Utrecht: Ambo.

\section{Kernbegrippe}

Bybel

Bybellees

Bybelverstaan

naïewe rasionalisme

\section{Key concepts}

Bible

Bible interpretation

Bible reading

naïve rationalism 
